\title{
Vitamin D deficiency in patients with cluster headache: a preliminary study
}

\author{
Jong-Hee Sohn ${ }^{1}$, Min-Kyung Chu' ${ }^{2}$, Kwang-Yeol Park ${ }^{3}$, Hong-Yup Ahn ${ }^{4}$ and Soo-Jin Cho ${ }^{5^{*}}$
}

\begin{abstract}
Background: Cluster headache is famous for attacks with seasonal and diurnal periodicity. This diurnal and seasonal variation might be related to sunlight and vitamin D metabolism. We investigated the serum vitamin D levels in patients with cluster headache.

Methods: We enrolled patients with cluster headache and age- and sex-matched migraineurs and normal controls. From October 2016 to March 2018, non-fasting serum 25(OH)D concentrations were measured using a chemiluminescent immunoassay. Vitamin D deficiency was defined as a concentration $<20 \mathrm{ng} / \mathrm{mL}$.

Results: The study enrolled 28 patients with cluster headache, 36 migraineurs, and 36 normal controls. In the patients with cluster headache, the serum 25(OH)D concentration averaged $14.0 \pm 3.9 \mathrm{ng} / \mathrm{mL}$ and $92.8 \%$ had vitamin D deficiency. There was no significant difference among the patients with cluster headache, migraineurs, and controls. In the patients with cluster headache, there was no difference in the serum 25(OH)D concentrations between men and women, cluster and remission periods, first and recurrent attack, presence and absence of daily or seasonal periodicity, and 3-month recurrence. In the 14 patients with seasonal periodicity, patients with periodicity of winter to spring had a trend of lower serum 25(OH)D concentrations than those with periodicity of summer to autumn $(12.30 \pm 1.58 \mathrm{vs} .16 .96 \pm 4.69 \mathrm{ng} / \mathrm{mL}$, $p=0.097)$.

Conclusions: Vitamin D deficiency is common in patients with cluster headache, but the role of vitamin D deficiency is uncertain, except for its seasonal influence.
\end{abstract}

Keywords: Vitamin D, Deficiency, Cluster headache, Migraine

\section{Background}

Vitamin D is produced in the skin after oral absorption and exposure to sunlight. It is transformed by the liver and kidneys and plays a crucial role in promoting bone and muscle health. Vitamin D deficiency is a global health issue and is associated with inflammation, autonomic function, autoimmune disorders, chronic pain, cancer, and vascular and neurological disorders, in addition to its skeletal roles [1-6].

The estimated prevalence of vitamin D deficiency in North America, Europe and Australia is as high as 20$50 \%$ [7-13]. Vitamin D deficiency is more common in Korea $\left(37^{\circ} \mathrm{N}\right)$ where the prevalence in male and female adult workers was 69.5 and $83.1 \%$, respectively [14]. The

\footnotetext{
* Correspondence: dowonc@naver.com

${ }^{5}$ Department of Neurology, Dongtan Sacred Heart Hospital, Hallym University College of Medicine, Keun Jae Bong-gil 7, Hwaseong, Gyeonggi-do 18450, Korea

Full list of author information is available at the end of the article
}

determinants of vitamin D levels are the amount of skin exposure, followed by location, season, personal ultraviolet radiation exposure, vitamin D supplementation, body mass index, and physical activity [15].

A high prevalence of all kinds of headache has been associated with high latitude, suggesting a relationship with vitamin D [16]. However, the inter-relationships of vitamin $\mathrm{D}$ deficiency and headache are still uncertain. The studies of vitamin D in primary headache disorders have focused mainly on migraine, although there is no systematic evidence of an association between vitamin $\mathrm{D}$ deficiency and migraine [17-19]. There are case reports of migraine patients who improved with vitamin D supplementation [20, 21]. Simvastatin plus vitamin D has been reported to be effective for preventing headache in adults with episodic migraine in randomized clinical trials [22]. Dysfunction of vitamin D-binding protein and polymorphism of the vitamin $\mathrm{D}$ receptor gene have been 
reported in patients with migraine, while the relationship between the serum vitamin $\mathrm{D}$ level and headache frequency in migraine patients is controversial [23-25].

Tension-type headache is the most common primary headache disorder, accounting for most non-migraine headache in population studies. In the Norwegian population, non-migraine type headache was associated with low vitamin D levels with an odds ratio of 1.20 in the lowest quartile compared with the highest quartile group, whereas no significant association was found between migraine and the vitamin D levels [17]. There are also reports that chronic tension-type headache was associated with vitamin D deficiency [26-28].

Cluster headache shows a seasonal predilection, with nocturnal attacks [29-31]. The diurnal and seasonal variation might be related to sunlight and vitamin D metabolism, suggesting a role for vitamin D in cluster headache. There are no published studies of vitamin D in cluster headache, although a poster presentation showed that an anti-inflammatory regimen of vitamin and mineral supplements including vitamin D3 was effective in preventing cluster headaches [32]. Therefore, we investigated the serum vitamin $\mathrm{D}$ level in patients with cluster headache and the relationship between vitamin D deficiency and headache parameters compared with migraineurs and healthy controls.

\section{Methods}

\section{Subjects}

We enrolled patients with cluster headache and age- and sex-matched migraine patients as headache controls and normal controls in a case-control design. This study collected data from patients with cluster headache and migraine treated in the headache clinics of Chuncheon, Dongtan, and Kangnam Sacred Heart Hospitals of Hallym University College of Medicine from October 2016 to March 2018. All participants were between 20 and 65 years of age, and they were examined and classified according to the beta version of the International Classification of Headache Disorders-3 (ICHD-3 $\beta$ ) [33] by a board-certified neurologist based on the patient history, a neurological examination, and neuroimaging studies. The control group consisted of volunteers matched for age, gender, and season enrolled. We recruited the control group via advertisements such as posted notices in the hospital. Control participants were required to be headache free (less than 1 headache day per month for an average of 1 year) with no history of primary or secondary headache disorder by the ICHD-3 $\beta$ $[31,33]$. Exclusion criteria included subjects who took a vitamin $\mathrm{D}$ supplement or medication that influences vitamin D metabolism (e.g., antiepileptic drugs, rifampin, antiretroviral drugs, etc.), severe obesity [body mass index $(B M I)>30]$, thyroid or parathyroid disease, diabetes, and severe liver or renal disease.
The study protocol and informed consent form were reviewed and approved by the Institutional Review Board of each hospital (2016-439-I). Written informed consent was obtained from all participants before enrolling them in the study.

\section{Demographic data and questionnaire}

Demographic data were obtained from all groups, including age, sex, height, weight, place of residence, occupation, level of education, and smoking habit. The data collected on headache patients included frequency of attacks (per month), average headache duration (hours), severity of pain [assessed with a visual analogue scale (VAS) range 010], and days per month using abortive medication. The patients with cluster headache completed a detailed semi-structured questionnaire on the headache characteristics, such as autonomic symptoms, diurnal periodicity, time of propensity, and seasonal periodicity. We contacted the patients after at least 3 months and collected data on the recurrence of headache. Eligible patients were interviewed at follow-up outpatient appointments or by telephone. The headache group completed the Headache Impact Test-6 (HIT-6) to measure headache-related impact, Patient Health Questionnare-9 (PHQ-9) to assess depression, Generalized Anxiety Dirorder-7 (GAD-7) to assess anxiety, and Pittsburgh Sleep Quality Index (PSQI) to measure the quality of sleep [34-37].

\section{Measurement and analysis of vitamin D}

Non-fasting venous blood samples were collected at the baseline examinations. Serum 25(OH)D concentrations were measured with a chemiluminescent immunoassay using the ARCHITECT i4000 SR (Abbott Diagnostics, IL, USA). The intra- and interassay coefficients of variation of the measurements were $1.7-2.8$ and $2.7-4.1 \%$, respectively. The assay was standardized against NIST Standard Reference Material 2972 (NIST, Gaithersburg, ME, USA) and certified by the Centers for Disease Control and Prevention Vitamin D Standardization Program [38]. Vitamin D deficiency was defined as a $25(\mathrm{OH}) \mathrm{D}<20 \mathrm{ng} / \mathrm{mL}$, insufficiency as $21-29 \mathrm{ng} / \mathrm{mL}$, and ideal range as $30-50 \mathrm{ng} / \mathrm{mL}$.

The time of the day, month, and year when the vitamin D assessment was performed was recorded [39, 40]. Most experts define vitamin D deficiency as serum $25(\mathrm{OH}) \mathrm{D}$ vitamin D levels $<20 \mathrm{ng} / \mathrm{mL}$, although there is no consensus on the optimal serum vitamin D levels [41-44]. A cutoff value of $20 \mathrm{ng} / \mathrm{mL}$ was used to divide the samples into "deficient" and "normal" groups in this study [14].

\section{Statistics}

Analysis of variance (ANOVA) was used to compare demographic and headache parameters among groups, after confirming the normality of the distribution using the Shapiro-Wilk test. If the normality of the 
distribution was not confirmed, the Kruskal-Wallis, chi-square test or Fisher's exact test were used to compare data between groups, where appropriate. Serum vitamin D concentrations in subjects with $\mathrm{CH}$, migraine, and controls were compared using analysis of covariance (ANCOVA), with adjustment for potential confounders. The correlations between the serum $25(\mathrm{OH}) \mathrm{D}$ concentration and various clinical features were assessed using Pearson's or Spearman correlation coefficient based on the normality of the distribution.

To compare vitamin D concentration according to the headache parameters among the $\mathrm{CH}$ group, the Mann-Whitney test was used. ANOVA was used to compare vitamin D concentrations between subgroups in $\mathrm{CH}$ patients. Using linear regression analysis, we calculated the odds ratios of vitamin D levels associated with the headache variables. The variables that showed statistical correlations with the vitamin D levels in the univariate analyses, and factors that are known to affect the vitamin D level, were included in the multivariate regression analysis. Linear regression was used to assess the seasonal propensity of serum $25(\mathrm{OH}) \mathrm{D}$ concentrations with factors known to affect vitamin D levels (age, male, current smoker, sampling time) [45]. A $p$-value $<0.05$ was considered statistically significant. All analyses were performed using $\mathrm{R}$ version 3.5.0 for Windows ( $\mathrm{R}$ Foundation for Statistical Computing, Vienna, Austria. http://www.r-project.org/) and RStudio version 1.1.442.

\section{Results}

Comparison of demographics and vitamin D levels in patients with cluster headache, migraine, and controls

The study enrolled 28 patients with cluster headache, 36 migraineurs, and 36 normal controls. No significant differences were found in the $\mathrm{CH}$ and migraine patients compared with the controls in terms of age (38.2, 35.1, and 35.4 years, respectively) or sex (proportion male 85.7, 80.6, and $88.9 \%$, respectively). In addition, there were no differences in BMI, smoking status, sampling season, and sampling time zones (7-10 AM, 11 AM-1 PM, 2-5 PM) among the three groups (Table 1).

The serum 25(OH)D concentrations were $14.0 \pm$ $3.9 \mathrm{ng} / \mathrm{mL}$ in the patients with $\mathrm{CH}, 14.7 \pm 5.9 \mathrm{ng} / \mathrm{mL}$ in the migraineurs, and $14.6 \pm 7.4 \mathrm{ng} / \mathrm{mL}$ in the normal controls $(p=0.884)$. After adjustment for potential confounders (sex, age, sampling season, current smoking) by ANCOVA, the serum 25(OH)D concentrations were not different between groups (data not shown, $p=$ 0.853). Vitamin D deficiency was present in $92.8 \%$ of the patients with $\mathrm{CH}, 80.6 \%$ of the migraineurs, and $83.3 \%$ of the normal controls $(p=0.771)$ There were no significant differences in distribution of serum $25(\mathrm{OH}) \mathrm{D}$ concentrations between patients with $\mathrm{CH}$, migraine, and controls (Table 1).

Serum 25(OH)D concentrations were higher in those with a sampling season from summer to autumn than those with a sampling season from winter to spring (15.6 \pm $5.2 \mathrm{ng} / \mathrm{mL}$ vs. $13.3 \pm 6.5 \mathrm{ng} / \mathrm{mL}, p=0.003)$. No differences

Table 1 Demographic features and vitamin D parameters of the patients with cluster headache, migraineurs, and normal controls

\begin{tabular}{|c|c|c|c|c|}
\hline & Cluster Headache $(n=28)$ & Migraine $(n=36)$ & Normal controls $(n=36)$ & $p$-value \\
\hline Age, years & $38.2 \pm 8.5$ & $35.1 \pm 8.2$ & $35.4 \pm 9.1$ & 0.189 \\
\hline Men (\%) & $24(85.7)$ & $29(80.6)$ & $32(88.9)$ & 0.607 \\
\hline $\mathrm{BMl}, \mathrm{kg} / \mathrm{m}^{2}$ & $23.3 \pm 2.8$ & $23,6 \pm 3.7$ & $24.1 \pm 3.2$ & 0.583 \\
\hline Smoking habit (\%) ${ }^{a}$ & & & & 0.133 \\
\hline Current & $17(63.0)$ & $15(41.7)$ & $14(38.9)$ & \\
\hline ex-smoker & $3(11.1)$ & $2(5.6)$ & $8(22.2)$ & \\
\hline Never & $7(25.9)$ & $19(52.8)$ & $14(38.9)$ & \\
\hline Pain intensity, VAS & $8.5 \pm 1.8$ & $6.4 \pm 1.7$ & NA & $<0.001$ \\
\hline Vitamin D deficiency (\%) & $26(92.8)$ & $29(80.6)$ & $30(83.3)$ & 0.771 \\
\hline Distribution of $25(\mathrm{OH}) \mathrm{D}$ concentration & & & & 0.236 \\
\hline$\geq 30(\mathrm{ng} / \mathrm{mL})$ & 0 & $1(2.8)$ & $2(5.6)$ & \\
\hline $20-29.9(\mathrm{ng} / \mathrm{mL})$ & $2(7.2)$ & $6(16.7)$ & $4(11.1)$ & \\
\hline $10-19.9(\mathrm{ng} / \mathrm{mL})$ & $23(82.1)$ & $21(58.3)$ & 19 (52.8) & \\
\hline$<10(\mathrm{ng} / \mathrm{mL})$ & $3(10.7)$ & $8(22.2)$ & $11(30.5)$ & \\
\hline Sampling seasons & & & & 0.349 \\
\hline Winter to spring & $15(53.9)$ & $21(58.3)$ & $15(41.7)$ & \\
\hline Summer to autumn & $13(46.4)$ & $15(41.7)$ & $21(58.3)$ & \\
\hline
\end{tabular}

Values are expressed as mean \pm standard deviation or number (\%) VAS visual analogue scale

${ }^{\text {a }}$ data was not available in one patient with $\mathrm{CH}$ 
in serum vitamin $\mathrm{D}$ concentrations were evident based on the time of blood sample collection when analyzed at one-hour intervals (data not shown). Furthermore, there were no correlations between serum 25(OH)D concentrations and age, BMI, GAD-7 score, or PHQ-9 score, nor were any differences of the level observed between sexes.

\section{Comparison of vitamin D levels in the patients with cluster headache according to clinical factors}

In patients with $\mathrm{CH}$, there was no difference in the serum $25(\mathrm{OH}) \mathrm{D}$ concentrations between men and women, cluster and remission periods, first and recurrent attack, presence and absence of daily or seasonal periodicity, and 3 -month recurrence $(p>0.05)$. In the 14 patients with seasonal periodicity, patients with periodicity of winter to spring had a trend toward lower serum 25(OH)D concentrations than those with periodicity of summer to autumn $(12.30 \pm 1.58$ vs. $16.96 \pm 4.69 \mathrm{ng} / \mathrm{mL}, p=0.097$, Table 2$)$.

Vitamin D levels were significantly lower in the subgroup with sampling season between winter to spring relative to other groups. Therefore, we analyzed vitamin D levels in the $\mathrm{CH}$ subgroups according to seasonal propensity, and by sample season for the $22 \mathrm{CH}$ patients with recurrence (Table 3). There were significant differences in vitamin D levels between six groups; however, the differences between sampling seasons were not significant. There was no correlation between the vitamin D level and daily frequency, average weeks of cluster period, total bout of cluster period, or HIT-6, GAD-7, or PHQ-9 score.

\section{Clinical factors associated with vitamin D levels}

The univariate linear analysis showed that sampling from summer to autumn and seasonal propensity for summer to autumn showed significant correlations with the vitamin $\mathrm{D}$ level. In the multiple linear regression analysis, however, the significance of seasonal propensity for summer to autumn was lost after adjusting for the sampling season. No changes in significance were observed by the multiple linear regression analysis when controlling for age, current smoking status, and sampling time zone (Additional file 1: Table S1).

\section{Discussion}

This study suggested that vitamin D deficiency is very common in patients with cluster headache compared with the prevalence of vitamin D deficiency in Korean adults [14]. However, the significance of vitamin D deficiency is uncertain, except for a subtle seasonal influence.

A few recent observational studies suggested that low serum vitamin D levels were related to some headache disorders, especially migraine and tension-type headache [24, 28, 46, 47]. One study also reported significant relations of lifetime prevalence of both migraine and tension-type headache with latitude [16]. If vitamin D has
Table 2 Vitamin D levels according to clinical variables in the patients with cluster headache

\begin{tabular}{|c|c|c|}
\hline & $25(\mathrm{OH}) \mathrm{D}, \mathrm{ng} / \mathrm{mL}$ & $p$-value \\
\hline Sex & & 0.646 \\
\hline Men $(n=24)$ & $13.95 \pm 4.08$ & \\
\hline Women $(n=4)$ & $14.33 \pm 2.82$ & \\
\hline Recurrence & & 0.300 \\
\hline First episode $(n=6)$ & $14.83 \pm 2.42$ & \\
\hline Recurrent episode $(n=22)$ & $13.78 \pm 4.21$ & \\
\hline Paired comparison & & 0.421 \\
\hline Cluster period $(n=14)$ & $13.87 \pm 3.64$ & \\
\hline Remission period $(n=14)$ & $14.06 \pm 4.56$ & \\
\hline Diurnal periodicity & & 0.728 \\
\hline Present $(n=16)$ & $13.69 \pm 3.47$ & \\
\hline Absent $(n=12)$ & $14.41 \pm 4.50$ & \\
\hline Time of propensity & & 0.125 \\
\hline Nighttime propensity $(n=9)$ & $14.72 \pm 3.63$ & \\
\hline Daytime propensity $(n=7)$ & $11.71 \pm 2.63$ & \\
\hline Recurrence at 3 months & & 0.562 \\
\hline present $(n=2)$ & $13.00 \pm 3.39$ & \\
\hline absent $(n=26)$ & $14.08 \pm 3.97$ & \\
\hline Seasonal periodicity & & 0.188 \\
\hline Present $(n=14)$ & $14.63 \pm 4.14$ & \\
\hline Absent $(n=8)$ & $12.29 \pm 4.18$ & \\
\hline Season of cluster period & & 0.097 \\
\hline Winter to spring $(n=7)$ & $12.30 \pm 1.58$ & \\
\hline Summer to autumn $(n=7)$ & $16.96 \pm 4.69$ & \\
\hline Sampling season & & 0.001 \\
\hline Winter to spring $(n=15)$ & $11.91 \pm 2.63$ & \\
\hline Summer to autumn $(n=13)$ & $16.41 \pm 3.76$ & \\
\hline
\end{tabular}

any association with headache, the prevalence of headache should match the seasonal variation in vitamin D levels. There are data indicating an increased frequency of headache attacks in autumn-winter and the least number of attacks in summer, although there are few studies on the seasonal variation of primary headache disorders, such as migraine and tension-type headache [48-50].

However, the relationship between cluster headache and vitamin D has not been studied previously, although cluster headache has characteristic seasonal rhythmicity. Cluster headache is a primary headache disorder characterized by a unique seasonal and diurnal periodicity. These characteristic features of its periodicity suggest involvement of the hypothalamus, the biological clock [51]. In Korea, seasonal propensity and diurnal periodicity were present in 44.0 and $68.5 \%$ of the patients with cluster headache, respectively. Among patients with seasonal propensity and diurnal periodicity, the most frequently cited season and time was spring 
Table 3 The 25(OH)D concentration according seasonal propensity and sample seasons in $22 \mathrm{CH}$ patients with recurrence

\begin{tabular}{|c|c|c|c|c|}
\hline \multirow{2}{*}{$\begin{array}{l}\text { According to sample } \\
\text { seasons }\end{array}$} & \multicolumn{2}{|l|}{ Seasonal propensity } & \multirow{2}{*}{$\begin{array}{l}\text { No seasonal } \\
\text { propensity }(n=8)\end{array}$} & \multirow[t]{2}{*}{$p$-value } \\
\hline & Winter to spring $(n=7)$ & Summer to autumn $(n=7)$ & & \\
\hline Winter to spring $(n=12)$ & $12.28 \pm 1.93^{\mathrm{a}}(n=5)$ & $13.00 \pm 3.39^{c}(n=2)$ & $9.48 \pm 1.61^{\mathrm{e}}(n=5)$ & 0.001 \\
\hline Summer to autumn $(n=10)$ & $12.35 \pm 0.07^{\mathrm{b}}(n=2)$ & $18.54 \pm 4.38^{\mathrm{d}}(n=5)$ & $16.97 \pm 1.82^{f}(n=3)$ & \\
\hline
\end{tabular}

One-way analysis of variance (ANOVA) was done based on normal distribution of vitamin D level among 28 patients with cluster headache. According to post-hoc analysis between 6 groups using Turkey HSD, $p$-values between a and $\mathrm{d}$ was $0.023, p$-value between $\mathrm{d}$ and e was $<0.001$, and $p$-value between e and $\mathrm{f}$ was 0.018 . The other comparisons were not significant

$\mathrm{CH}$ cluster headache

(37.5\%) and night (66.4\%), respectively [52]. An inverse relationship between sunshine duration and the monthly incidence of cluster periods was reported in a hospital-based study [53]. A follow-up population-based study found positive correlations between average temperature and sunshine duration with occurrence of cluster periods, and that temperature was associated with precipitating or priming cluster periods [30]. Based on previous results, it is possible that vitamin D and cluster headaches are related. However, our study did not find significant differences in the vitamin $\mathrm{D}$ level among cluster headache, migraine, and controls. Although there was no significant difference among groups, the prevalence of vitamin D deficiency was higher in the cluster headache group than in the migraine and control groups. This suggests that vitamin D deficiency is very common in patients with cluster headache compared with the prevalence of vitamin D deficiency in Korean adults [14]. There was also no significant difference in vitamin D levels according to clinical variables in the patients with cluster headache. However, patients with periodicity of winter to spring had a trend of lower serum 25(OH)D concentrations than those with periodicity of summer to autumn in patients with seasonal periodicity. The serum vitamin $\mathrm{D}$ level varies with the season, peaking in May to September. The levels tend to be lower from November to March [54-56]. Therefore, we used an arbitrary classification of the sunny season, i.e., summer to autumn, winter to spring.

The vitamin D receptor and $1 \alpha$-hydroxylase, the enzyme responsible for the formation of the active vitamin, are present in many parts of the central nervous system, including the prefrontal cortex, hippocampus, cingulate gyrus, thalamus, and hypothalamus. The strongest immunohistochemical staining for both the receptor and enzyme was in the hypothalamus [57]. Vitamin D-binding protein was also detected in axonal projections throughout the lateral hypothalamus in the rat [58]. The presence of the vitamin D receptor, $1 \alpha$-hydroxylase, and vitamin D-binding protein in the hypothalamus suggests a role of vitamin D deficiency in the generation of various primary headache disorders. In addition to the hypothalamus, there is evidence that the pineal gland has a role in the biological regulation of circadian rhythms by producing melatonin [59]. Sunshine has been reported to regulate specific hormonal and neurotransmitter levels, including melatonin [60]. Altered melatonin levels have been documented in cluster headache and the nocturnal serum melatonin level was decreased during cluster periods [61]. Based on the characteristic clinical features and proposed mechanisms of cluster headache, we hypothesized that vitamin D and cluster headache are related. However, our study failed to find any correlations between the serum vitamin $\mathrm{D}$ levels and headache characteristics, such as the seasonal and circadian rhythmicity of cluster headache or the association between serum vitamin $\mathrm{D}$ levels and recurrence of cluster headache. To determine the associations between vitamin $\mathrm{D}$ and the recurrence in cluster headache, a further longitudinal follow-up study of a larger population is required.

Various factors influence serum vitamin D levels, making, it is difficult to speculate on the role of vitamin D in the pathophysiology of cluster headache. Our study could not control for all of the environmental and demographic factors that significantly affect the serum vitamin D levels There was no information on the exposure of the subjects to sunlight, their sun protection habits or the extent of vitamin D supplementation through food, though we did collect information on smoking status, BMI, sampling time, and sampling season, all of which are known to influence vitamin D concentration. We also analyzed the influence of these variables on serum vitamin D levels. There were no significant differences in smoking status and BMI among the three groups. Additionally, current smoking was not a significant determinant of serum vitamin D levels in this study population using multivariate regression analysis. Second, our study had a relatively small sample size due to the rarity of cluster headache. This study suggests that the influence of vitamin D may warrant analysis in a larger cohort of $\mathrm{CH}$ patients with seasonal propensity for winter to spring. This study also included mostly men, due to a sex-matched research design, so these findings may not be truly representative of migraine and normal controls, or generalizable to other groups. Third, the outcome variables collected, such as the seasonal propensity, were assessed on self-report by recall and the classification of the sunny season was arbitrary. While we did not obtain fasting serum samples, there were no significant differences in sampling times among the three groups based on the time the blood samples were collected. 


\section{Conclusions}

In summary, this is the first report to examine serum vitamin $\mathrm{D}$ levels in patients with $\mathrm{CH}$ compared to those of age-and sex-matched controls controlling for sampling season as well as other clinical variables.. Our preliminary findings suggest that vitamin D deficiency is very common in patients with cluster headache, but the significance of vitamin D deficiency is uncertain, except for the subtle seasonal influence. Further research is needed to determine the role of vitamin $\mathrm{D}$ in $\mathrm{CH}$.

\section{Additional file}

Additional file 1: Table S1. Coefficients of linear regression analysis of the vitamin D levels in $22 \mathrm{CH}$ patients with recurrence. (DOCX $14 \mathrm{~kb}$ )

\section{Abbreviations}

BMI: Body mass index; GAD-7: Generalized Anxiety Dirorder-7; HIT6: Headache Impact Test-6; ICHD-3ß: Beta version of the International Classification of Headache Disorders-3; PHQ-9: Patient Health Questionnare-9; PSQI: Pittsburgh Sleep Quality Index; SE: Standard error; VAS: Visual analogue scale

\section{Acknowledgements}

Thanks to my research coordinator, Jung Eun Kwon for sincere cooperation during the procedure.

\section{Funding}

This study was supported by Hallym University Research Fund (HURF2016-54). The role of funding was in the design of the study and collection, analysis, and interpretation of data. No other financial relationships relevant to this publication were disclosed.

\section{Availability of data and materials}

Available as supplementary data

\section{Authors' contributions}

Conception and design of the experiments: SJC, KYP, JHS, MKC, HYA; Performance of data collection: SJC, JHS, MKC; Data analysis: SJC, KYP, HYA. Writing of the manuscript and final approval: SJC, KYP, JHS, MKC, HYA.

\section{Ethics approval and consent to participate}

The study protocol and informed consent form were reviewed and approved by the Institutional Review Board of each hospital (Dongtan Sacred Heart Hospital approval no. 2016-439-I; Chuncheon Sacred Heart Hospital approval no. 2016-131; Kangnam Sacred Heart Hospital approval no. 2016-11-157). Written informed consent was obtained from all participants before enrolling them in the study.

\section{Consent for publication}

Not applicable

\section{Competing interests}

The authors declare that they have no competing interests.

\section{Publisher's Note}

Springer Nature remains neutral with regard to jurisdictional claims in published maps and institutional affiliations.

\section{Author details}

${ }^{1}$ Department of Neurology, Chuncheon Sacred Heart Hospital, Hallym University College of Medicine, Chuncheon-si, Gangwon-do, Korea.

${ }^{2}$ Department of Neurology, Severance Hospital, Yonsei University College of
Medicine, Seoul, Korea. ${ }^{3}$ Department of Neurology, Chung-Ang University Hospital, Chung-Ang University College of Medicine, Seoul, Korea. ${ }^{4}$ Department of Statistics, Dongguk University-Seoul, Seoul, Korea. ${ }^{5}$ Department of Neurology, Dongtan Sacred Heart Hospital, Hallym University College of Medicine, Keun Jae Bong-gil 7, Hwaseong, Gyeonggi-do 18450, Korea.

Received: 13 May 2018 Accepted: 9 July 2018

Published online: 17 July 2018

\section{References}

1. Gagnon C, Lu ZX, Magliano DJ, Dunstan DW, Shaw JE, Zimmet PZ, Sikaris K, Grantham N, Ebeling PR, Daly RM (2011) Serum 25hydroxyvitamin D, calcium intake, and risk of type 2 diabetes after 5 years: results from a national, population-based prospective study (the Australian diabetes, obesity and lifestyle study). Diabetes Care 34(5): 1133-1138. https://doi.org/10.2337/dc10-2167

2. Ju SY, Lee YJ, Jeong SN (2013) Serum 25-hydroxyvitamin D levels and the risk of depression: a systematic review and meta-analysis. J Nutr Health Aging 17(5):447-455. https://doi.org/10.1007/s12603-012-0418-0

3. Afzal S, Bojesen SE, Nordestgaard BG (2014) Reduced 25-hydroxyvitamin D and risk of Alzheimer's disease and vascular dementia. Alzheimers Dement 10(3):296-302. https://doi.org/10.1016/j.jalz.2013.05. 1765

4. Autier P, Boniol M, Pizot C, Mullie P (2014) Vitamin D status and ill health: a systematic review. Lancet Diabetes Endocrinol 2(1):76-89. https://doi.org/10. 1016/s2213-8587(13)70165-7

5. Chen WR, Qian YA, Chen YD, Shi Y, Yin d W, Wang H, Zhu P, Liu HW, Sha Y (2014) The effects of low vitamin D on coronary artery disease. Heart Lung Circ 23(4):314-319. https://doi.org/10.1016/j.hlc.2013.08.012

6. Annweiler C, Dursun E, Feron F, Gezen-Ak D, Kalueff AV, Littlejohns T, Llewellyn DJ, Millet P, Scott T, Tucker KL, Yilmazer S, Beauchet O (2015) Vitamin D and cognition in older adults': updated international recommendations. J Intern Med 277(1):45-57. https://doi.org/10.1111/joim.12279

7. Gill TK, Hill CL, Shanahan EM, Taylor AW, Appleton SL, Grant JF, Shi Z, Dal Grande E, Price K, Adams RJ (2014) Vitamin D levels in an Australian population. BMC Public Health 14:1001. https:/doi.org/10.1186/1471-2458-14-1001

8. Ginde AA, Liu MC, Camargo CA Jr (2009) Demographic differences and trends of vitamin D insufficiency in the US population, 1988-2004. Arch Intern Med 169(6):626-632. https://doi.org/10.1001/archinternmed.2008.604

9. Greene-Finestone LS, Berger C, de Groh M, Hanley DA, Hidiroglou N, Sarafin K, Poliquin S, Krieger J, Richards JB, Goltzman D (2011) 25-Hydroxyvitamin D in Canadian adults: biological, environmental, and behavioral correlates. Osteoporos Int 22(5):1389-1399. https://doi.org/10.1007/s00198-010-1362-7

10. Hypponen E, Power C (2007) Hypovitaminosis D in British adults at age 45 y: nationwide cohort study of dietary and lifestyle predictors. Am J Clin Nutr 85(3):860-868. https://doi.org/10.1093/ajcn/85.3.860

11. Looker AC, Dawson-Hughes B, Calvo MS, Gunter EW, Sahyoun NR (2002) Serum 25-hydroxyvitamin D status of adolescents and adults in two seasonal subpopulations from NHANES III. Bone 30(5):771-777

12. Rockell JE, Skeaff CM, Williams SM, Green TJ (2006) Serum 25-hydroxyvitamin D concentrations of New Zealanders aged 15 years and older. Osteoporos Int 17(9):1382-1389. https://doi.org/10.1007/s00198-006-0118-x

13. Thuesen $B$, Husemoen $L$, Fenger $M$, Jakobsen J, Schwarz P, Toft $U$, Ovesen L, Jorgensen T, Linneberg A (2012) Determinants of vitamin D status in a general population of Danish adults. Bone 50(3):605-610. https://doi.org/10.1016/j.bone.2011.12.016

14. Jeong H, Hong S, Heo Y, Chun H, Kim D, Park J, Kang MY (2014) Vitamin D status and associated occupational factors in Korean wage workers: data from the 5th Korea national health and nutrition examination survey (KNHANES 2010-2012). Ann Occup Environ Med 26: 28. https://doi.org/10.1186/s40557-014-0028-x

15. Kimlin MG, Lucas RM, Harrison SL, van der Mei I, Armstrong BK, Whiteman DC, Kricker A, Nowak M, Brodie AM, Sun J (2014) The contributions of solar ultraviolet radiation exposure and other determinants to serum 25hydroxyvitamin D concentrations in Australian adults: the AusD study. Am J Epidemiol 179(7):864-874. https://doi.org/10.1093/aje/kwt446

16. Prakash S, Mehta NC, Dabhi AS, Lakhani O, Khilari M, Shah ND (2010) The prevalence of headache may be related with the latitude: a possible role of vitamin D insufficiency? J Headache Pain 11(4):301-307. https://doi.org/10.1007/s10194-010-0223-2 
17. Kjaergaard M, Eggen AE, Mathiesen EB, Jorde R (2012) Association between headache and serum 25-hydroxyvitamin D: the Tromso study: Tromso 6. Headache 52(10):1499-1505. https://doi.org/10.1111/j.1526-4610.2012.02250.x

18. Lippi G, Cervellin G, Mattiuzzi C (2014) No evidence for an association of vitamin $D$ deficiency and migraine: a systematic review of the literature. Biomed Res Int 2014:827635. https://doi.org/10.1155/2014/827635

19. Zandifar A, Masjedi SS, Banihashemi M, Asgari F, Manouchehri N, Ebrahimi H, Haghdoost F, Saadatnia M (2014) Vitamin D status in migraine patients: a casecontrol study. Biomed Res Int 2014:514782. https:/doi.org/10.1155/2014/514782

20. Thys-Jacobs S (1994) Vitamin D and calcium in menstrual migraine. Headache 34(9):544-546

21. Mottaghi T, Askari G, Khorvash F, Maracy MR (2015) Effect of vitamin D supplementation on symptoms and C-reactive protein in migraine patients. J Res Med Sci 20(5):477-482

22. Buettner C, Nir RR, Bertisch SM, Bernstein C, Schain A, Mittleman MA Burstein R (2015) Simvastatin and vitamin D for migraine prevention: a randomized, controlled trial. Ann Neurol 78(6):970-981. https://doi.org/ 10.1002/ana.24534

23. Motaghi M, Haghjooy Javanmard S, Haghdoost F, Tajadini M, Saadatnia M, Rafiee L, Zandifar A (2013) Relationship between vitamin D receptor gene polymorphisms and migraine without aura in an Iranian population. Biomed Res Int 2013:351942. https://doi.org/10.1155/2013/351942

24. Mottaghi T, Khorvash F, Askari G, Maracy MR, Ghiasvand R, Maghsoudi Z, Iraj B (2013) The relationship between serum levels of vitamin D and migraine. J Res Med Sci 18(Suppl 1):S66-S70

25. Nagata E, Fujii N, Hosomichi K, Mitsunaga S, Suzuki Y, Mashimo Y, Tsukamoto H, Satoh T, Osawa M, Inoue I, Hata A, Takizawa S (2014) Possible association between dysfunction of vitamin D binding protein (GC globulin) and migraine attacks. PLoS One 9(8):e105319. https://doi.org/10.1371/ journal.pone.0105319

26. Prakash S, Makwana P, Rathore C (2016) Vitamin D deficiency mimicking chronic tension-type headache in children. BMJ Case Rep 2. https://doi.org/10.1136/bcr-2015-213833

27. Prakash S, Rathore C, Makwana P, Dave A, Joshi H, Parekh H (2017) Vitamin $D$ deficiency in patients with chronic tension-type headache: a case-control study. Headache 57(7):1096-1108. https://doi.org/10.1111/head.13096

28. Prakash S, Shah ND (2009) Chronic tension-type headache with vitamin D deficiency: casual or causal association? Headache 49(8):1214-1222. https://doi.org/10.1111/j.1526-4610.2009.01483.x

29. Rozen TD, Fishman RS (2012) Cluster headache in the United States of America: demographics, clinical characteristics, triggers, suicidality, and personal burden. Headache 52(1):99-113. https://doi.org/10.1111/j.15264610.2011.02028.x

30. Lee YJ, Chen YT, Ou SM, Li SY, Yang AC, Tang CH, Wang SJ (2014) Temperature variation and the incidence of cluster headache periods: a nationwide population study. Cephalalgia 34(9):656-663. https://doi.org/10. 1177/0333102413520083

31. Barloese MC (2015) Neurobiology and sleep disorders in cluster headache. J Headache Pain 16:562. https://doi.org/10.1186/s10194-015-0562-0

32. Peter $B$ (2014) A survey of cluster headache $(\mathrm{CH})$ sufferers using vitamin D3 as a $\mathrm{CH}$ preventative. Poster presented of the 66th Annual meeting of American Acedemy of Neurology, Philadelphia, April 26-May 03, 2014

33. Headache Classification Committee of the International Headache Society (IHS) (2013) The International Classification of Headache Disorders, 3rd edition (beta version). Cephalalgia 33(9):629-808. https://doi.org/10.1177/0333102413485658

34. Buysse DJ, Reynolds CF, Monk TH, Berman SR, Kupfer DJ (1989) The Pittsburgh sleep quality index: a new instrument for psychiatric practice and research. Psychiatry Res 28(2):193-213

35. Chu MKIH, Ju YS, Yu KH, Ma HI, Kim YJ et al (2009) Validity and reliability assessment of Korean headache impact test-6 (HIT-6). J Korean Neurol Assoc 2009(27):1-6

36. Seo JG, Park SP (2015) Validation of the patient health questionnaire-9 (PHQ-9) and PHQ-2 in patients with migraine. J Headache Pain 16:65. https://doi.org/10.1186/s10194-015-0552-2

37. Seo J-G, Park S-P (2015) Validation of the generalized anxiety disorder-7 (GAD-7) and GAD-2 in patients with migraine. J Headache Pain 16(1):97

38. CDC Vitamin D Standardization-Certification Program (VDSCP)_-Total 25hydroxy Vitamin D Certified Procedures (2017) https://www.cdc.gov/ labstandards/pdf/hs/CDC_Certified_Vitamin_D_Procedures.pdf. Accessed 8 Dec 2017
39. Holick MF (2017) The vitamin D deficiency pandemic: approaches for diagnosis, treatment and prevention. Rev Endocr Metab Disord 18(2):153165. https://doi.org/10.1007/s11154-017-9424-1

40. Holick MF, Binkley NC, Bischoff-Ferrari HA, Gordon CM, Hanley DA, Heaney RP, Murad MH, Weaver CM (2011) Evaluation, treatment, and prevention of vitamin D deficiency: an endocrine society clinical practice guideline. J Clin Endocrinol Metab 96(7):1911-1930. https://doi.org/10.1210/jc.2011-0385

41. Thomas MK, Lloyd-Jones DM, Thadhani RI, Shaw AC, Deraska DJ, Kitch BT, Vamvakas EC, Dick IM, Prince RL, Finkelstein JS (1998) Hypovitaminosis D in medical inpatients. N Engl J Med 338(12):777783. https://doi.org/10.1056/nejm199803193381201

42. Malabanan A, Veronikis IE, Holick MF (1998) Redefining vitamin D insufficiency. Lancet 351(9105):805-806

43. Hollis BW, Wagner CL (2005) Normal serum vitamin D levels. N Engl J Med 352(5): 515-516; author reply 515-516. https://doi.org/10.1056/nejm200502033520521

44. Holick MF (2006) High prevalence of vitamin D inadequacy and implications for health. Mayo Clin Proc 81(3):353-373. https://doi.org/10.4065/81.3.353

45. Masood T, Kushwaha RS, Singh R, Sailwal S, Pandey H, Varma A, Singh RK, Cornelissen G (2015) Circadian rhythm of serum $25 \mathrm{OH}$ vitamin D, calcium and phosphorus levels in the treatment and management of type-2 diabetic patients. Drug Discov Therap 9(1):70-74. https://doi.org/10.5582/ddt.2015.01002

46. Prakash S, Kumar M, Belani P, Susvirkar A, Ahuja S (2013) Interrelationships between chronic tension-type headache, musculoskeletal pain, and vitamin D deficiency: is osteomalacia responsible for both headache and musculoskeletal pain? Ann Indian Acad Neurol 16(4):650-658. https://doi.org/10.4103/0972-2327.120487

47. Celikbilek A, Gocmen AY, Zararsiz G, Tanik N, Ak H, Borekci E, Delibas N (2014) Serum levels of vitamin D, vitamin D-binding protein and vitamin D receptor in migraine patients from Central Anatolia region. Int J Clin Pract 68(10):1272-1277. https://doi.org/10.1111/ijcp.12456

48. Soriani S, Fiumana E, Manfredini R, Boari B, Battistella PA, Canetta E, Pedretti S, Borgna-Pignatti C (2006) Circadian and seasonal variation of migraine attacks in children. Headache 46(10):1571-1574. https://doi. org/10.1111/j.1526-4610.2006.00613.x

49. Marrelli A, Marini C, Prencipe M (1988) Seasonal and meteorological factors in primary headaches. Headache 28(2):111-113

50. Cugini P, Romit A, Di Palma L, Giacovazzo M (1990) Common migraine as a weekly and seasonal headache. Chronobiol Int 7(5-6):467-469

51. Pringsheim T (2002) Cluster headache: evidence for a disorder of circadian rhythm and hypothalamic function. Can J Neurol Sci 29(1):33-40

52. Heui-Soo Moon JWP, Kwang-Soo Lee C-SC, Byung-Kun Kim J-MK, Jong-Hee Sohn MKC, Oh K, Cho SJ (2017) Clinical features of cluster headache patients in Korea. J Korean Med Sci 32(3):502-506. https:// doi.org/10.3346/jkms.2017.32.3.502

53. Lin KH, Wang PJ, Fuh JL, Lu SR, Chung CT, Tsou HK, Wang SJ (2004) Cluster headache in the Taiwanese - a clinic-based study. Cephalalgia 24(8):631638. https://doi.org/10.1111/j.1468-2982.2003.00721.x

54. Rapuri PB, Kinyamu HK, Gallagher JC, Haynatzka V (2002) Seasonal changes in calciotropic hormones, bone markers, and bone mineral density in elderly women. J Clin Endocrinol Metab 87(5):2024-2032. https://doi.org/10.1210/jcem.87.5.8475

55. Prince PB, Rapoport AM, Sheftell FD, Tepper SJ, Bigal ME (2004) The effect of weather on headache. Headache 44(6):596-602. https://doi. org/10.1111/j.1526-4610.2004.446008.x

56. Maxwell JD (1994) Seasonal variation in vitamin D. Proc Nutr Soc 53(3):533-543

57. Eyles DW, Smith S, Kinobe R, Hewison M, McGrath JJ (2005) Distribution of the vitamin $\mathrm{D}$ receptor and 1 alpha-hydroxylase in human brain. J Chem Neuroanat 29(1):21-30. https://doi.org/10.1016/j.jchemneu.2004.08.006

58. Jirikowski GF, Kaunzner UW, Dief Ael E, Caldwell JD (2009) Distribution of vitamin $D$ binding protein expressing neurons in the rat hypothalamus. Histochem Cell Biol 131(3):365-370. https://doi.org/10.1007/s00418-008-0540-6

59. Peres MF (2005) Melatonin, the pineal gland and their implications for headache disorders. Cephalalgia 25(6):403-411. https://doi.org/10. 1111/j.1468-2982.2005.00889.x

60. Golombek DA, Rosenstein RE (2010) Physiology of circadian entrainment. Physiol Rev 90(3):1063-1102. https://doi.org/10.1152/physrev.00009.2009

61. Waldenlind E, Gustafsson SA, Ekbom K, Wetterberg L (1987) Circadian secretion of cortisol and melatonin in cluster headache during active cluster periods and remission. J Neurol Neurosurg Psychiatry 50(2):207-213 